of purchase. On November 2, Prof. J. H. Clapham, rice-provost of King's College, Cambridge, performed the ceremony of opening at Ruislip, Middlesex, the "Little Barn" (so called for generations) appertaining to the ancient Manor of Ruislip, and now being used as a county library. The homestead of the farm, it should be said, originally constituted, with the acres around, but a fraction indeed of the extensive tracts owned formerly at Ruislip by King's College, Cambridge, the gift of its founder, Henry VI. Not long ago, the College conveyed the farm and surrounds to the people of Ruislip as a gift. Hence the presence of Prof. Clapham was specially opportune and relevant to the occasion. The requisite funds for the adaptation and library furnishing equipment of the barn for its new purposes were provided by the Middlesex County Council, supported by the unwearied efforts of the Middlesex Education Committee. It is of interest to record that Mr. T. E. James, formerly clerk to the Royal Society, who lives at Ruislip, has been appointed by the Middlesex County Council as a representative on the Ruislip-Northwood Local Library Committee.

\section{Oils from Irish Grown Plants}

Cork University Press has issued an Agricultural Bulletin, No. 4, with this title. It contains the record of some small-scale experiments, carried out at Cork and elsewhere in the Irish Free State, on the possibility of producing supplies of oil seeds upon Irish soils. Crops of hemp, linseed, poppy, sunflower, rape, mustard and Mercurialis annua have been raised with varying success, and the yield of oils determined, as also the main physical chemical characteristics of the extracted oils. The work has been under the direction of Prof. J. Reilly and Mr. Denis F. Kelly, of the Department of Chemistry, University College, Cork. Very indifferent success was met with in these preliminary trials with the annual sunflower and Mercurialis, and the authors seem most impressed with the possibilities of native-grown poppy seed oil displacing cotton seed oil in the edible fat and soap industries in Ireland. These trials are, however, of a very preliminary nature; they throw very little light upon the possibility or otherwise of large-scale cultivation of these crops under Irish conditions, but they do establish the yields and main characteristics of the oils to be expected from such oil seeds grown under such conditions.

\section{Horticultural Research in Australia}

The opening in September of a new laboratory under the Commonwealth Council for Scientific and Industrial Research at Merbein, Victoria, is an indication of the store now set by viticulturists on the provision of scientific services for their guidance. Merbein is in the Mildura district on the River Murray, where the first irrigation settlements were established some fifty years ago. Marked changes have taken place of late in horticultural practices in these areas, following particularly upon studies of soils with consequent modification of quantity and frequency of watering, and upon introduction of communal drainage schemes. The former danger of ruin of blocks by 'salting', or bringing sodium sulphate and chloride and other salts to the surface by excessive watering and insufficient drainage, is almost a thing of the past. The Council is now preparing plans for a further new laboratory at its citricultural research station at Griffith, N.S.W., in an area watered from the Burrinjuck Dam on the Murrumbidgee River.

\section{National Institute of Agricultural Botany}

$\mathrm{ON}_{\mathrm{N}}$ the occasion of the annual general meeting of fellows of the National Institute of Agricultural Botany at Cambridge, the chairman of the council, Captain D. M. Wills, directed attention to the value of the Institute's system of substations. By means of this organization the Institute is able to make recommendations to farmers which are applicable to all districts (with two exceptions) south of a line drawn between Lancaster and Scarborough. There are at present two defective links in the Institute's chain of substations - the Fens and Wales-and the Institute hopes that these defects will shortly be remedied. At present there are substations at Sprowston, Norfolk ; Long Sutton, Hants ; Cannington, Somerset; Newport, Shropshire ; and Askham Bryan, Yorks; on soils ranging from blowing sand to heavy clay. In every case these substations are attached to an agricultural college, institute or station, and the trials are carried out under the supervision of a crop recorder who is responsible to the N.I.A.B. Although the primary purpose of a substation is the provision of trials upon which recommendations can be based, Captain Wills stressed the importance of another aspect of their work. It is possible for a farmer to visit any of these to see, under conditions which may be very similar to his own, trials of the latest introductions of plant breeders both at home and abroad, growing side by side with established varieties. This should enable him to form an opinion as to the suitability-or otherwise- of new varieties to his particular conditions. Finally, Captain Wills expressed the hope that the establishment of a substation in Wales would lead to the discovery of varieties particularly suited to the poorer soils, both in England and Wales.

\section{Mass Observations of Social Problems}

"Mass-Observation" by C. Madge and T. Harrisson, with a foreword by Dr. Julian Huxley, the first of a series of projected pamphlets, outlines the technique of a study of social environment and its effects on lines comparable with much bird-watching and observation of natural history, since, largely because of its empiricism, it has, like them, room for the untrained amateur as well as for the trained man of science (London: Frederick Muller, Ltd., 1937. 1s. net). The three sciences most immediately relevant to mass-observation are psychology, anthropology and sociology, and a fundamental plan for research will be evolved by the central organization as a result of suggestions from observers and scientific experts. In the first place, it is intended to mobilize 